
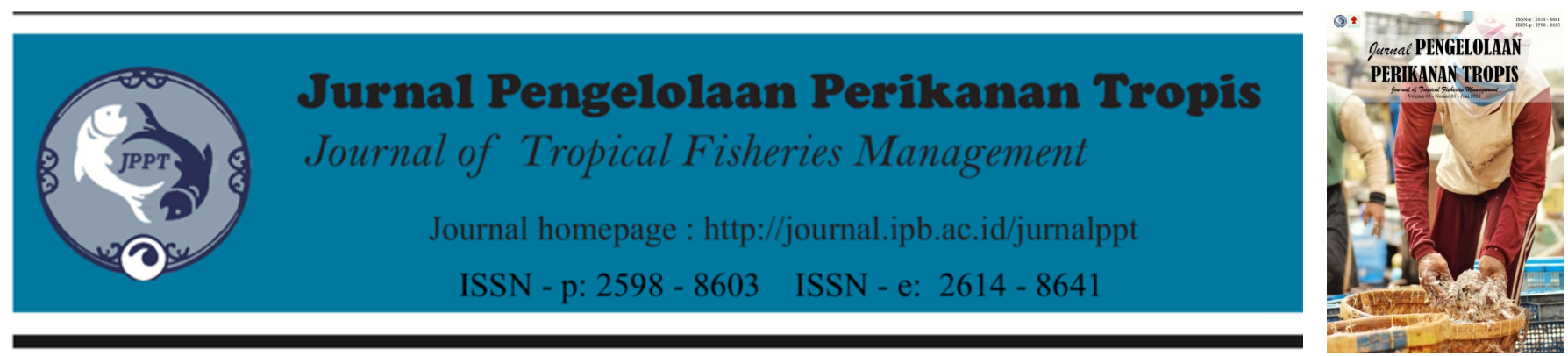

\title{
Analisis Orde Sungai Dan Distribusi Stadia Sebagai Dasar Penentuan Daerah Perlindungan Ikan Sidat (Anguilla spp.) Di DAS Cimandiri, Jawa Barat
}

\author{
(River Order Analysis and Fish Stadia Distribution as a Basis for Protected Areas Determination of \\ Freshwater Eel (Anguilla spp.) in Cimandiri Watershed, West Java)
}

\section{Agus Alim Hakim*, Mohammad Mukhlis Kamal, Nurlisa Alias Butet, Ridwan Affandi}

Departemen Manajemen Sumberdaya Perairan, Fakultas Perikanan dan Ilmu Kelautan, Institut Pertanian Bogor

\begin{tabular}{l}
\hline ARTIKEL INFO \\
\hline Article History \\
Recevied: 10 Januari 2019 \\
Accepted: 24 Maret 2019 \\
\hline \\
Kata Kunci: \\
DAS Cimandiri, daerah \\
perlindungan, konservasi, orde \\
sungai, sidat \\
\hline
\end{tabular}

\begin{abstract}
Korespondensi Author
Agus Alim Hakim,

Departemen Manajemen

Sumberdaya Perairan, Fakultas

Perikanan dan Ilmu Kelautan,

Institut Pertanian Bogor.

Email:

agusalimhakim0@gmail.com
\end{abstract}

\section{ABSTRAK}

Sungai merupakan habitat makhluk hidup dimana terjadi hubungan timbal balik antara makhluk hidup dengan lingkungannya. Sungai yang merupakan habitat ikan sidat (Anguilla spp.) harus tetap terjaga agar pertumbuhan dan perkembangan tidak terganggu serta keberadaannya tetap lestari. Ikan sidat pada stadia larva akan bermigrasi dari laut ke perairan sungai hingga hulu dan setelah dewasa akan kembali ke laut untuk memijah. Penelitian ini bertujuan untuk menganalisis orde sungai dan mengkaji distribusi stadia ikan sebagai dasar penentuan daerah perlindungan ikan sidat (Anguilla spp.) di DAS Cimandiri, Jawa Barat. Penelitian ini dilakukan pada bulan Desember 2014 dan April 2015 meliputi tracking sungai (pengamatan habitat sungai, pengamatan aktivitas penangkapan, dan wawancara), analisis orde sungai, dan penentuan distribusi tiap stadia ikan sidat. DAS Cimandiri memiliki panjang sebesar 69,5 km dengan komposisi sungai permanen (permanent) dan sungai periodik (intermittent) memiliki orde sungai dari 1 hingga 7. Terdapat 56 sungai permanen bagian DAS Cimandiri yang merupakan sungai dengan orde sungai 1 . Sungai dengan orde sungai 1 merupakan bagian hulu yang kondisi habitat dan perairannya masih baik. Beberapa dari bagian sungai yang memiliki orde sungai 1 dapat ditetapkan sebagai daerah perlindungan ikan sidat (Anguilla spp.). Distribusi berdasarkan stadia menunjukkan bahwa ikan sidat memiliki komposisi stadia yang tercampur, tetapi glass eels terdistibusi hanya pada $5 \mathrm{~km}$ dari arah laut. Adanya perbedaan stadia dari setiap bagian sungai maka diperlukan pengelolaan yang berbeda pula pada masing-masing bagian sungai tersebut.

\section{PENDAHULUAN}

Sungai merupakan habitat makhluk hidup dimana terjadi hubungan timbal balik antara makhluk hidup dengan lingkungannya. Sungai dengan segala sumber daya dapat dimanfaatkan dalam kehidupan sehari-hari bahkan dapat menjadi sumber mata pencaharian. Ikan merupakan salah satu sumber daya sungai yang dapat dimanfaatkan namun perlu dilestarikan agar dapat dimanfaatkan secara berkelanjutan. Di Indonesia terdapat banyak sungai yang memiliki potensi sumberdaya perikanan, begitu pula di daerah Jawa Barat. Teluk Palabuhanratu merupakan daerah yang memiliki potensi perikanan yang tinggi, salah satunya ditunjang oleh adanya beberapa sungai yang bermuara ke teluk tersebut. DAS Cimandiri merupakan sungai terpanjang dengan panjang sebesar 69,5 km (PSDA 2010). DAS Cimandiri terdiri dari sungai permanen (permanent) dan sungai periodik (intermittent).
Menurut Sriati (1998), Teluk Palabuhanratu merupakan salah satu daerah yang memiliki potensi dan aktivitas penangkapan ikan sidat yang tinggi. Beberapa hasil penelitian sebelumnya telah mengidentifikasi spesies ikan sidat secara morfologi dan molekuler didapatkan 3 spesies ikan sidat di Sungai Cimandiri yaitu $A$. bicolorbicolor, A. nebulosa nebulosa, dan A. marmorata (Fahmi \& Hirnawati 2010; Fahmi 2013; Fahmi et al. 2013; Hakim et al. 2015). Chino \& Arai (2010) menambahkan bahwa hasil tangkapan di muara Sungai Cimandiri didominasi oleh ikan sidat spesies $A$. bicolor bicolor.

Ikan sidat (Anguilla spp.) tergolong dalam ikan katadromus yaitu ikan yang bermigrasi diantara perairan tawar dan perairan laut. Selama pematangan seksual, ikan sidat berkembang menjadi silver eels dan kembali ke laut untuk memijah dan mati (Tesch et al. 2003; Aoyama 2009; Aarestrup et al. 2010; Arai et al. 2013). Menurut Miller (2009), ikan sidat mulai 
mengalami perubahan dan perkembangan morfologi tubuh setelah masuk ke perairan tawar. Larva akan beruaya ke hulu sungai dengan melawan arus sedangkan ikan sidat dewasa melakukan ruaya menuju laut mengikuti aliran sungai (Creutzberg 1961 in Tesch et al. 2003).

Ikan sidat merupakan sumber daya perikanan sebagai komoditas ekspor di berbagai negara (Affandi 2005). Pasar internasional sidat terutama di Jepang, Korea, Hongkong, dan negara Eropa seperti Belanda, Italia, Jerman, Denmark, Belgia, Swedia, dan Prancis (Tesch et al. 2003; Herianti 2005). Permintaan terhadap ikan sidat mengalami peningkatan dari tahun ketahun (Widyasari, 2013). Menurut Chino dan Arai (2010), eksploitasi terhadap sumber daya ikan sidat akan terjadi karena memiliki nilai ekonomis yang tinggi. Penggunaan alat tangkap dan metode penangkapan yang kurang tepat, peningkatan upaya penangkapan, Pembangunan, aktivitas masyarakat, dan keberadaan PLTU menjadi ancaman terhadap keberadaan sumber daya ikan sidat (Hakim et al. 2016). Adanya ancamanancaman tersebut maka diperlukan suatu pengelolaan yang tepat untuk mempertahankan sumber daya agar dapat dimanfaatkan secara berkelanjutan. Penelitian ini bertujuan untuk menganalisis orde sungai dan mengkaji distribusi stadia ikan sebagai dasar penentuan daerah perlindungan ikan sidat (Anguilla spp.) di DAS Cimandiri, Jawa Barat.

\section{METODE}

\section{Waktu dan Lokasi Penelitian}

Penelitian ini dilaksanakan di Daerah Aliran Sungai (DAS) Cimandiri sepanjang 69,5 km yang bermuara ke Teluk Palabuhanratu, Sukabumi, Jawa Barat. Kegiatan yang dilakukan meliputi tracking sungai dan wawancara. Tracking sungai dan wawancara dilakukan dua kali yaitu pada bulan Desember 2014 dan April 2015 dengan menggunakan sepeda motor dan mobil. Analsis orde sungai dan distribusi tiap stadia ikan sidat dilakukan di Departemen Manajemen Sumber Daya Perairan, Fakultas Perikanan dan Ilmu Kelautan, Institut Pertanian Bogor.

\section{Tracking sungai}

Kegiatan tracking sungai meliputi pengamatan habitat sungai, pengamatan aktivitas penangkapan, dan wawancara. Pengamatan habitat sungai dan aktivitas penangkapan dilakukan untuk mengetahui kondisi perairan dan lingkungan sekitar secara langsung. Tracking sungai dilakukan dengan menyusuri sungai dari hilir hingga hulu. Menyusuri mulai dari hilir menggunakan sepeda motor, namun setelah 15 $\mathrm{Km}$ tidak bisa dilajutkan karena medan yang sulit ditempuh. Kegiatan selanjutnya yaitu menyusuri menggunakan mobil melewati jalan yang lebih lebar dan mengunjungi titik-titik yang dirasa pentingf untuk melakukan pengamatan maupun wawancara.

\section{Wawancara}

Wawancara dilakukan dengan memilih responden berdasarkan metode purposif sampling. Responden dipilih berdasarkan peran dalam pemanfaatan sumber daya ikan sidat maupun habitatnya dan peran dalam pengelolaan terhadap sumber daya ikan sidat. Responden wawancara dalam penelitian ini meliputi nelayan dan masyarakat sebagai pemanfaat habitat ikan sidat. Wawancara lebih ditekankan pada distribusi ikan sidat berdasarkan stadia, lokasi penangkapan, dan aktivitas penangkapan sidat.

\section{Analisis Data}

Orde sungai Cimandiri ditentukan berdasarkan pada metode Strahler (1957). Dimana penentuan orde sungai menggunakan semua sungai baik sungai permanen maupun sungai periodik. Penomeran orde sungai dimulai dari angka 1 hingga angka selanjutnya. Penentuan sungai dengan "orde satu" yaitu anak sungai paling ujung dan muaran dari pertemuan dua sungai dengan "orde satu" akan menjadi sungai dengan "orde dua". Muaran dari pertemuan dua sungai dengan "orde dua" akan menjadi sungai dengan "orde tiga" dan aturan tersebut digunakan untuk penomeran dengan angka selanjutnya. Keseluruhan informasi distribusi setiap stadia dan orde sungai dianalisis secara spasial dalam bentuk peta. Analisis spasial dilakukan dengan menggunakan software ArcGIS 10.4 dengan peta dasar bersumber dari peta Rupa Bumi Indonesia (RBI) skala 1:25.000 Bakosurtanal/BIG.

\section{HASIL DAN PEMBAHASAN}

\section{Orde Sungai di DAS Cimandiri}

DAS Cimandiri terletak di 3 kabupaten/kota yaitu Kabupaten Sukabumi, Kota Sukabumi, dan Kabupaten Cianjur. Sebagian besar dari DAS Cimandiri terletak di Kabupaten Sukabumi. DAS Cimandiri terdiri dari sungai permanen (permanent) dan sungai periodik (intermittent) Sungai permanen (permanent) adalah sungai yang memilki air sepanjang tahun, sedangkan sungai periodik (intermittent) adalah sungai yang hanya memiliki air pada musim tertentu.

Pembuatan orde sungai mengalami kesulitan karena luas Daerah Aliran Sungai (DAS) yang cukup besar dan memiliki banyak cabang anak sungai. Mengurangi kesalahan dan mempermudah dalam pembuatan nomer orde sungai maka DAS tersebut dibagi menjadi lima 


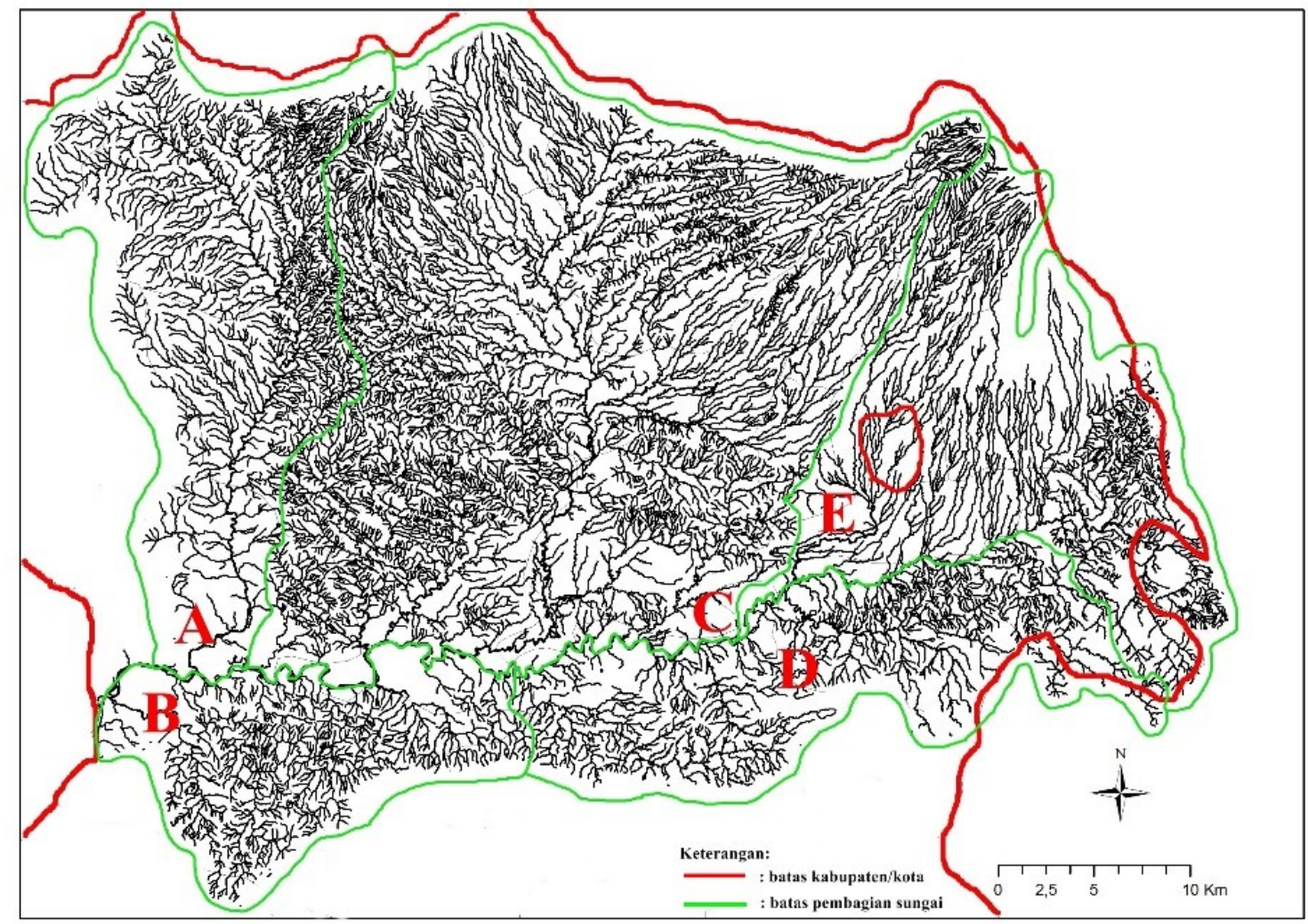

Gambar 1 Pembagian sungai dalam penentuan orde Sungai Cimandiri

bagian (Gambar 1). Gambar 1 menunjukkan pembagian DAS yaitu sungai bagian A (Gambar 2), sungai bagian $B$ (Gambar 3), sungai bagian $C$ (Gambar 4), sungai bagian D (Gambar 5), dan sungai bagian E (Gambar 6).

Sungai bagian A memiliki orde sungai dari orde 1 hingga orde 6 yang secara keseluruhan berada di Kabupaten Sukabumi. Sungai bagian B memiliki orde sungai dari orde 1 hingga orde 5 yang secara keseluruhan berada di Kabupaten Sukabumi. Sungai bagian C memiliki orde sungai dari orde 1 hingga orde 7 yang secara keseluruhan juga berada di Kabupaten Sukabumi. Sungai bagian D memiliki orde sungai dari orde 1 hingga orde 5 yang berada di Kabupaten Sukabumi dan Kabupaten Cianjur. Sungai yang melewati Kabupaten Cianjur hanya memiliki sungai dengan orde sungai 1 dan 2. Sedangkan sungai yang melewati Kabupaten Sukabumi memiliki sungai dengan orde sungai mulai dari 1 hingga 5. Sungai bagian $\mathrm{E}$ memiliki orde sungai dari orde 1 hingga orde 6 yang berada di Kabupaten Sukabumi, Kota Sukabumi, dan Kabupaten Cianjur. Sungai yang melewati Kabupaten Cianjur memiliki sungai dengan orde sungai 1 hingga 5 . Sungai yang melewati Kabupaten Sukabumi memiliki sungai dengan orde sungai 1 hingga 6 . Sungai yang melewati Kota Sukabumi memiliki sungai dengan orde sungai 1 hingga 4.

Secara keseluruhan, Kabupaten Sukabumi memiliki sungai dengan orde sungai 1 hingga 7. Kota Sukabumi memiliki sungai dengan orde sungai 1 hingga 4. Sedangkan Kabupaten Cianjur memiliki sungai dengan orde sungai 1 hingga 5.
Pengelolaan sumber daya dilakukan pada sumber daya yang selalu ada dalam setiap tahunnya, dalam hal ini sungai yang akan dikelola haruslah sungai yang terdapat sumber daya air sepanjang tahun. Untuk itu, pada penelitian ini memisahkan antara sungai permanen dengan sungai periodik. Didapatkan peta sungai permanen pada Sungai Cimandiri yang melewati beberapa kecamatan di Kabupaten Sukabumi. Orde sungai dari sungai permanen pada Sungai Cimandiri disajikan pada Gambar 7. Gambar 7 sangat membantu dalam penentuan kawasan perlindungan habitat bagi ikan sidat. Terdapat 56 bagian sungai yang memiliki orde sungai 1 .

Sungai dengan orde sungai 1 merupakan bagian hulu yang kondisi habitat dan perairannya masih baik. Biasanya orde 1 pada sungai permanen merupakan mata air sungai. Daerah tersebut layak dijadikan daerah perlindungan sumber daya. Sungai Cimandiri memiliki sumber mata air utama dari dua gunung yaitu Gunung Gede dan Gunung Salak. Gunung Gede merupakan gunung yang berada di wilayah tiga kabupaten yaitu Kabupaten Sukabumi, Kabupaten Cianjur, dan Kabupaten Bogor. Di Kabupaten Sukabumi, Gunung Gede berada pada Kecamatan Sukaraja dan Kecamatan Sukabumi yang terdapat banyak bagian sungai berorde 1. Sedangkan Gunung Salak merupakan gunung yang berada di wilayah dua kabupaten yaitu Kabupaten Sukabumi dan Kabupaten Bogor. Gunung Salak di Kabupaten Sukabumi berada pada Kecamatan Cidahu dan Kecamatan Parakansalak yang juga banyak terdapat bagian sungai dengan orde 1 . 

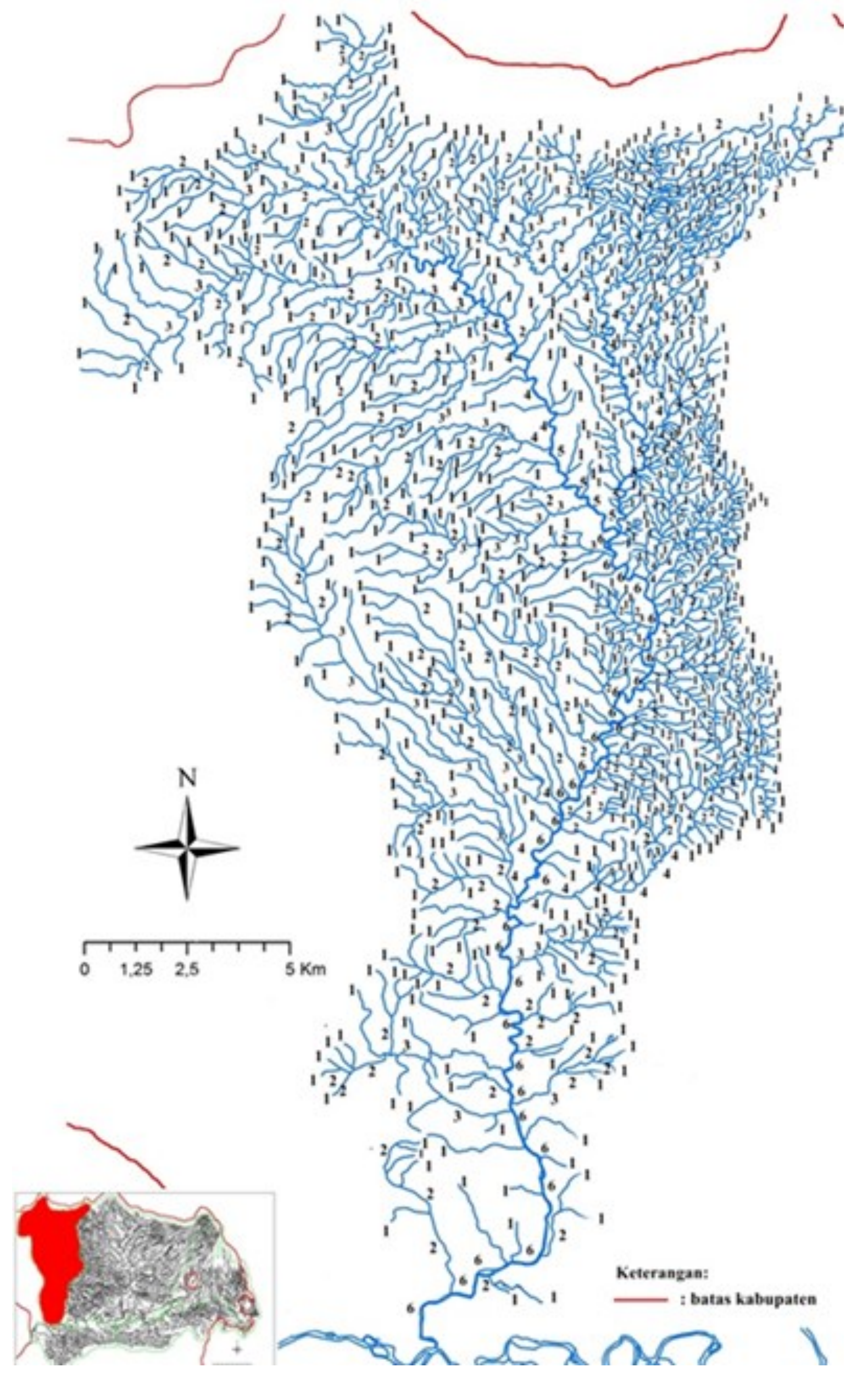

Gambar 2 Sungai bagian A dalam pembuatan orde Sungai 


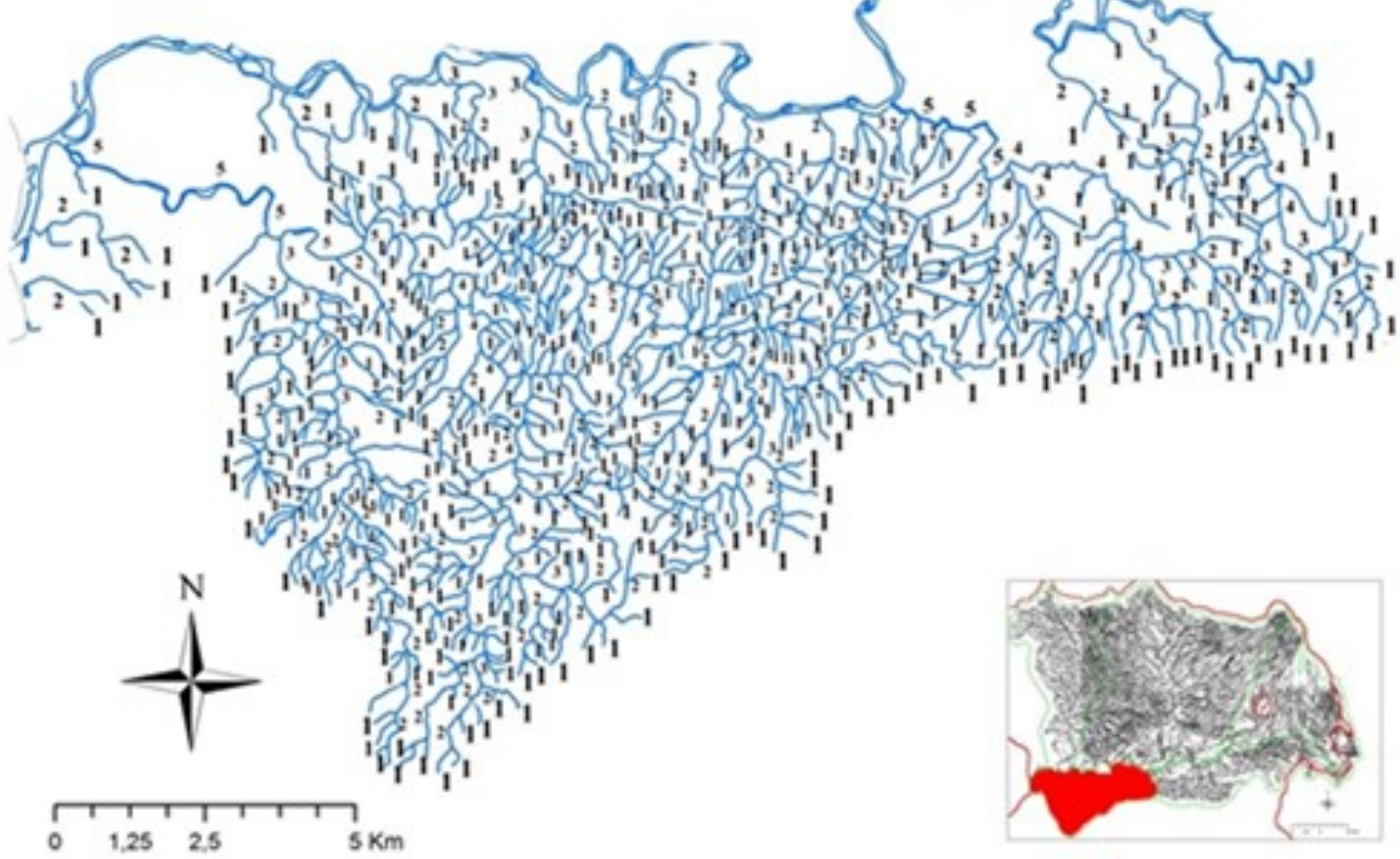

Gambar 3 Sungai bagian B dalam pembuatan orde Sungai

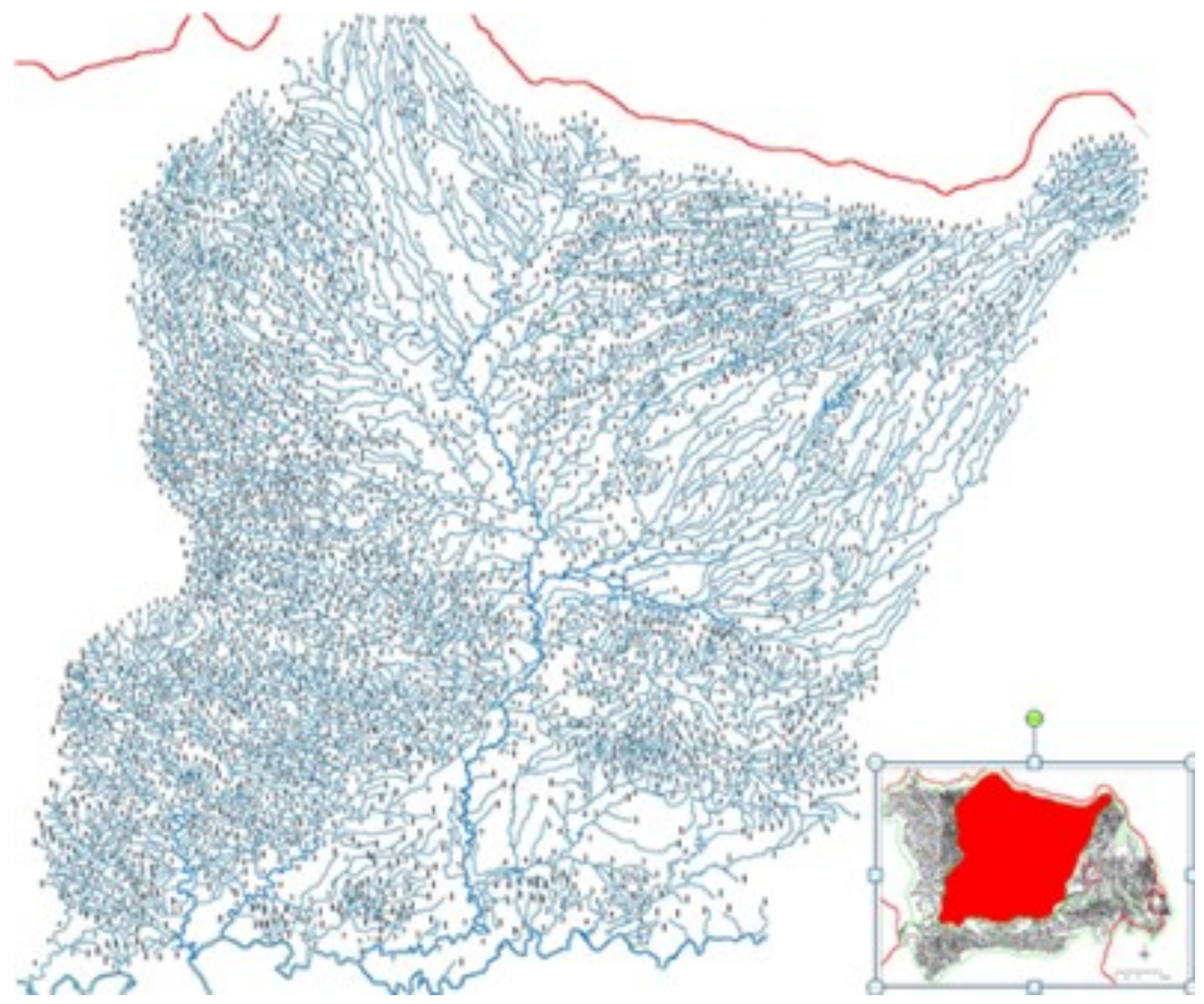

Gambar 4 Sungai bagian C dalam pembuatan orde Sungai 


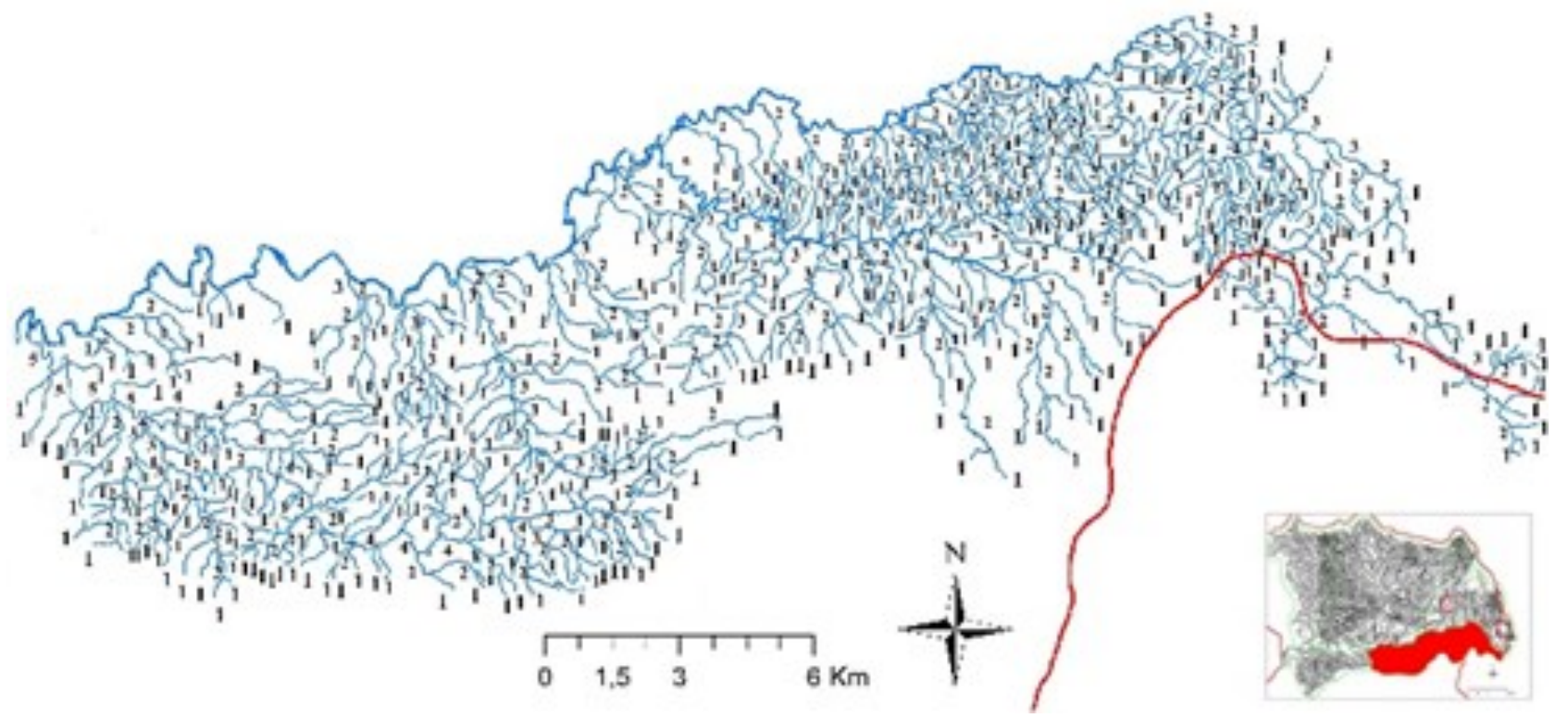

Gambar 5 Sungai bagian D dalam pembuatan orde Sungai

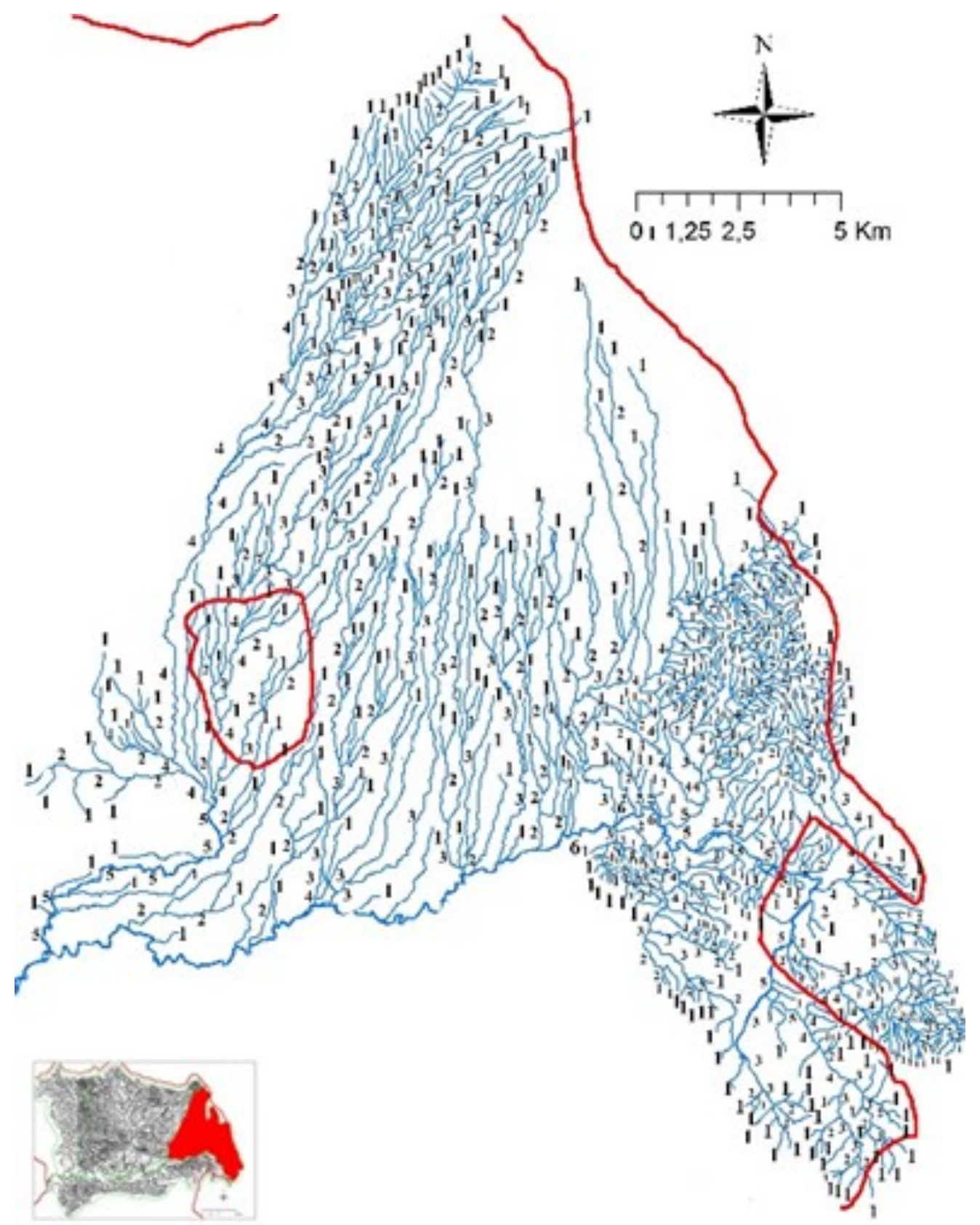

Gambar 6 Sungai bagian E dalam pembuatan orde Sungai 


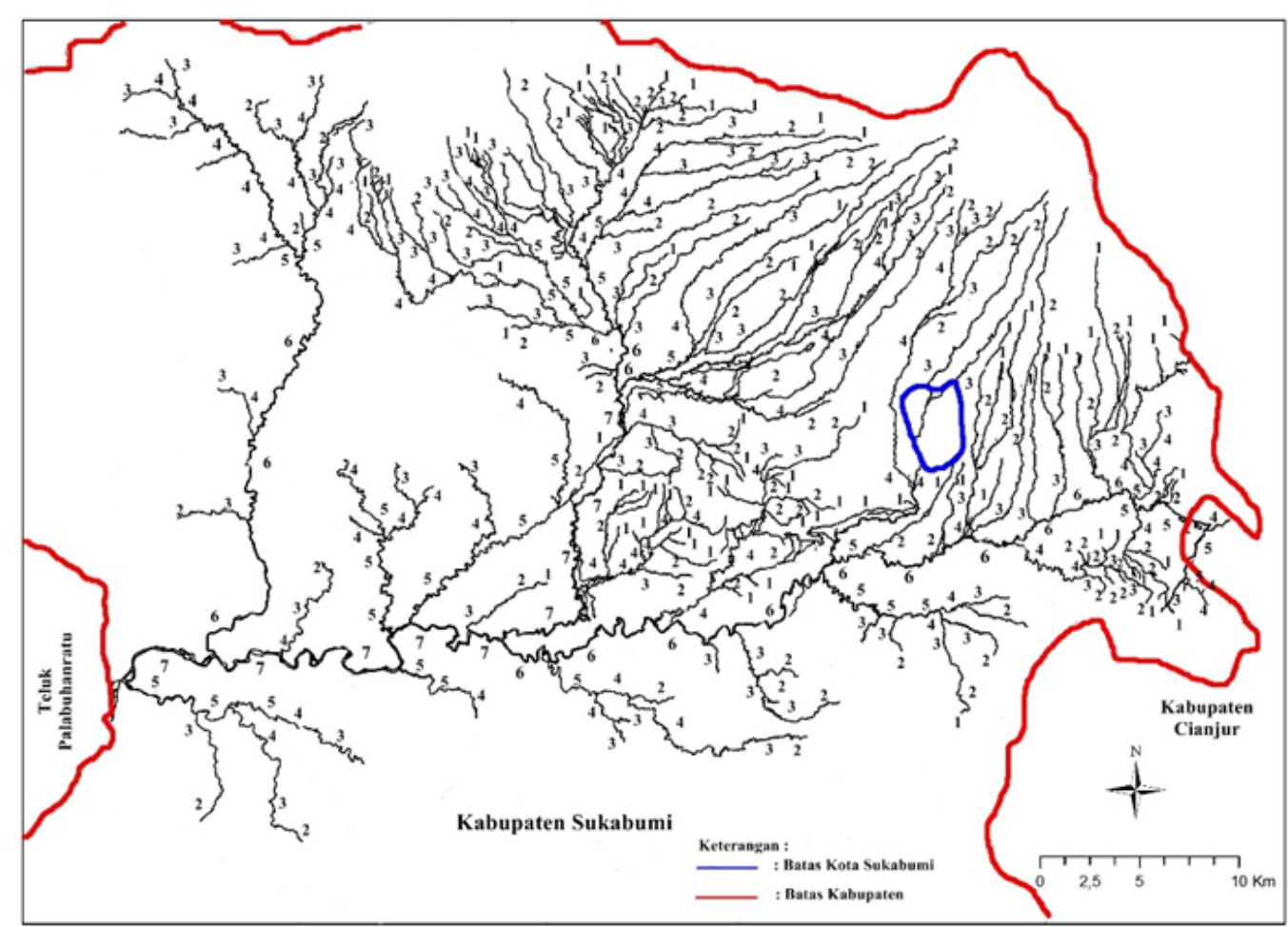

Gambar 7 Orde sungai dari sungai permanen pada Sungai Cimandiri yang melewati Kabupaten Sukabumi, Kabupaten Cianjur, dan Kota Sukabumi

\section{Distribusi Stadia Ikan Sidat}

Ikan sidat memiliki beberapa stadia dalam siklus hidupnya. Stadia hidup dimulai dari larva (leptocephalus), glass eels, elvers, yellow eels, dan silver eels. Menurut Tesch et al. (2003), sidat memijah di laut dalam, telur menetas menjadi larva (leptocephalus), terbawa oleh turbulensi arus ke arah tepi laut. Leptocephalus berkembang menjadi glass eels yang mulai memasuki perairan sungai atau estuari, pada stadia ini terjadi perubahan pigmen tubuh. Glass eels berkembang menjadi elvers. Elvers berkembang menjadi yellow eels. Selama pematangan, ikan sidat berkembang menjadi silver eels dan kembali ke laut untuk memijah. Berdasarkan perkembangan pigmen dan ukuran tubuh, Silfvergrip (2009) mengklasifikasikan sidat menjadi sidat muda dan sidat dewasa. Sidat muda yaitu sidat yang telah memiliki perkembangan pigmentasi tubuh dan berukuran kurang dari $200 \mathrm{~mm}$ (sidat pada stadia elvers), sedangkan sidat dewasa yaitu sidat yang memiliki ukuran diatas $200 \mathrm{~mm}$ (yellow eels dan silver eels).

Stadia glass eels mulai memasuki muara sungai untuk bermigrasi keperairan hulu sungai. Sidat mengalami proses tumbuh dan berkembang menjadi stadia selanjutnya saat melakukan migrasi. Penelitian ini mencoba memetakan distribusi ikan sidat berdasarkan stadia. Informasi yang dikumpulkan berupa hasil tracking yaitu hasil pengamatan langsung, wawancara terhadap nelayan, dan masyarakat sekitar sungai. Informasi yang didapatkan berdasarkan pengalaman empiris nelayan.
Ikan sidat merupakan ikan yang unik karena melakukan migrasi hingga sungai orde 1 atau hulu sungai. Distribusi sidat dalam berbagai stadia dapat terlihat pada Gambar 8. Garis berwarna biru menunjukkan bahwa daerah tersebut didominasi oleh adanya ikan sidat pada stadia glass eels. Glass eels hanya terdistribusi sejauh $5 \mathrm{~km}$ dari muara sungai. Hal tersebut terlihat dari aktivitas penangkapan glass eels hanya sampai $5 \mathrm{~km}$ dari muara sungai. Glass eels ditangkap dengan alat tangkap anco. Garis berwarna hijau menunjukkan bahwa daerah tersebut terdapat sidat dalam berbagai stadia. Namun, tidak ditemukan glass eels pada daerah tersebut. Terdapat banyak nelayan yang memancing maupun menangkap ikan sidat dengan perangkap (alat tangkap semacam bubu). Garis berwarna kuning menunjukkan bahwa daerah tersebut belum dilakukan tracking, sehingga belum diketahui distribusi sidat yang ada di daerah tersebut. Garis berwarna kuning adalah Sungai Cidadap yang merupakan anak sungai dari Sungai Cimandiri. Penelitian Sriati (1998) menemukan bahwa di muara Sungai Cidadap ditemukan glass eels. Hal tersebut menunjukkan bahwa Sungai Cidadap dimungkinkan terdapat ikan sidat dalam berbagai stadia, namun distribusi berdasarkan stadia belum diketahui.

Distribusi ikan sidat dipengaruhi oleh kondisi fisik perairan sungai dan perairan laut. Ada kemungkinan kondisi fisik yang mempengaruhi yaitu arus sungai, kemiringan dasar sungai, debit air sungai, keadaan dasar perairan, dan pasang 


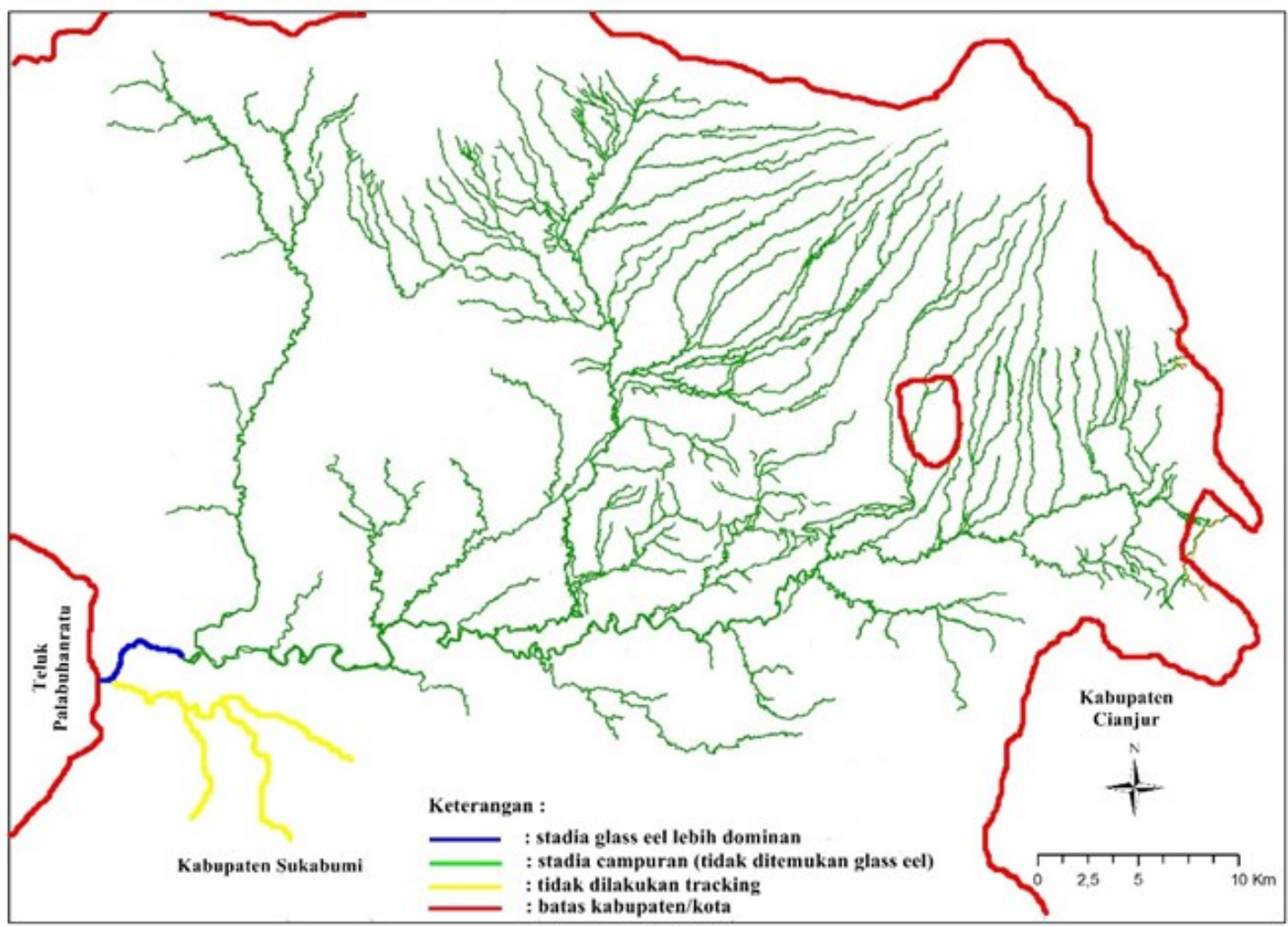

Gambar 8 Distribusi ikan sidat berdasarkan stadia di Sungai Cimandiri

surut. Glass eels hanya mampu memasuki sungai sejauh $5 \mathrm{~km}$. Glass eels bergerak lebih dipengaruh efek pasang surut air dan debit air. Apabila kemiringan dasar sungai rendah, maka pengaruh pasang surut dapat mencapai jauh ke arah daerah hulu, sehingga glass eels akan terbawa hingga jauh menuju hulu sungai. Stadia dewasa hampir ditemukan disetiap daerah sungai. Ikan dewasa mulai bergerak dari hulu menuju hilir sungai dan menuju ke laut untuk melakukan pemijahan.

\section{KESIMPULAN}

DAS Cimandiri memiliki komposisi sungai permanen (permanent) dan sungai periodik (intermittent) dari orde sungai dari 1 hingga 7. Terdapat 56 bagian DAS Cimandiri yang merupakan sungai dengan orde sungai 1 . Sungai dengan orde sungai 1 merupakan bagian hulu yang kondisi habitat dan perairannya masih baik. Beberapa dari bagian sungai yang memiliki orde sungai 1 dapat ditetapkan sebagai daerah perlindungan ikan sidat (Anguilla spp.). Distribusi berdasarkan stadia ikan sidat dengan komposisi stadia campuran tetapi glass eels terdistibusi hanya pada $5 \mathrm{~km}$ dari arah laut. Adanya perbedaan stadia dari setiap bagian sungai, maka diperlukan pengelolaan yang berbeda pula pada masing-masing bagian sungai tersebut.

\section{UCAPAN TERIMA KASIH}

Penelitian ini didanai oleh Pemerintah melalui Direktorat Pendidikan Tinggi tahun 2014.
Penulis mengucapkan terima kasih kepada Ibu Ati Rahadiati atas kemudahan kami mengakses dan mendapatkan peta. Terima kasih juga kepada Lalu Panji Imam Agamawan M.Si yang membantu mengendarai motor saat melakukan tracking sungai.

\section{DAFTAR PUSTAKA}

Aarestrup K, Thorstad E, Koed A. 2010. Survival and progression rates of large european Silver eel Anguilla anguilla in late freswater and early marine phases. Technical University of Denmark. 9:263-270.

Affandi R. 2005. Strategi pemanfaatan sumber daya Ikan Sidat. Jurnal Iktiologi Indonesia. 5 (2):77-81.

Aoyama J. 2009. Life history and evolution of migration in catadromous eels (Genus Anguilla). Aqua-BioSci. Monogr. 2(1):1-42.

Arai T, Chino N, Le DQ. 2013. Migration and habitat use of the tropical eels Anguilla marmorata and A. bicolor pacifica in Vietnam. Aquat Ecol. 47:57-65.

Chino N, Arai T. 2010. Habitat use and habitat transitions in the tropical eel Anguilla bicolor. Environ Biol Fish. 89(10):571-578.

Fahmi MR, Hirnawati. 2010. Keragaman ikan sidat tropis (Anguilla sp.) di perairan Sungai Cimandiri, Pelabuhan Ratu, Sukabumi. Prosiding Forum Inovasi Teknologi Akuakultur. 1-8.

Fahmi MR, Solihin DD, Soewardi K, Pouyaud L, Shao Z, Berrebi P. 2013. A novel semimultiplex PCR assay for identification of 
tropical eels of genus Anguilla in Indonesian waters. Fish Sci. 79:185-191.

Fahmi MR. 2013. Phylogeography of tropical eels (Anguilla spp) in Indonesia Waters [disertasi]. Bogor (ID): Institut Pertanian Bogor.

Hakim AA, Kamal MM, Butet NA, Affandi R. 2015. Komposisi spesies ikan sidat (Anguilla spp.) di delapan sungai yang bermuara ke teluk Palabuhanratu, Sukabumi, Indonesia. Jurnal Ilmu dan Teknologi Kelautan Tropis. 7(2):573-585.

Hakim AA, Kamal MM, Butet NA, Affandi R. 2016. Kondisi kualitas air sungai, aktivitas penangkapan, dan pemangku kepentingan (stakeholders) pada perikanan sidat di Das Cimandiri, Jawa Barat. 497 - 506 Prosiding Seminar Nasional Pengelolaan Pesisir Dan Daerah Aliran Sungai. Vol. 2 Universitas Gadjah Mada, Yogyakarta.

Herianti I. 2005. Rekayasa lingkungan untuk memacu perkembangan ovarium ikan sidat. Oseanografi dan Limnologi Indonesia. 37:25 $-41$.

Miller JM. 2009. Ecology of Anguilliform leptocephali remarkable transparent fish larvae of the ocean surface layer. AquaBioSci. Monogr. 2(4):1-94.

[PSDA] Pengelolaan Sumber Daya Air. 2010. Inventarisasi Sungai Non Lintas Kabupaten Sukabumi Balai PSDA Cisadea-Cimandiri. Jawa Barat. Cited in http:// psdajabarprov.go.id/ [18 November 2014]

Sriati. 1998. Telaah struktur dan kelimpahan populasi benih ikan sidat, Anguilla bicolor bicolor, di Muara Sungai Cimandiri, Palabuhan Ratu, Jawa Barat [tesis]. Bogor (ID): Institut Pertanian Bogor.

Strahler AN. 1957. Quantitative analysis of Watershed geomorphology. Transaction, American Geophysical Union. 38(6):913920.

Tesch FW, Bartsch P, Berg R, Gabriel O, Henderonn IW, Kamastra A, Kloppmann M, Reimer LW, Soffker K, Wirth T. 2003. The Eel. White RJ. penerjemah; Thorpe JE. editor. German (DE). Penerbit Blackwell Publishing Company.

Widyasari RAHE. 2013. Disain Pengembangan Industri Perikanan Sidat Indonesia Anguilla spp. berkelanjutan di Palabuhanratu Kabupaten Sukabumi Provinsi Jawa Barat [disertasi]. Bogor (ID): Institut Pertanian Bogor. 